\title{
Travel on the Web
}

\section{Sites to help you plan your vacation}

\author{
by Brian Coutts
}

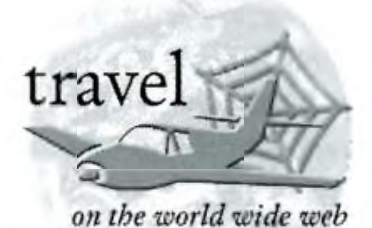

The UCLA Internet Report 2001, published in November 2001, found that 72.3 percent of Americans were online in 2001, up 5.4 percent from 2000. On the other hand, online purchasing at 48.9 percent was down from 50.7 percent the previous year. One of the most popular things people buy online is travel. The survey found that 11.6 percent of new users (online less than a year) made a travel-related purchase in 2001 compared with 20.7 percent of experienced users (online five or more years).

With more than 1,000 commercial travel sites and many more personal ones, it is sometimes a difficult task to select the best, reliable travel sources. While the number of visitors to Internet travel sites plummeted after the events of September 11, within three weeks, traffic at the three largest commercial travel sites, Expedia, Travelocity, and Orbitz, had already returned to preattack levels, according to one newspaper source.

On January 29, 2002, the New York Times reported that Expedia Inc.'s gross bookings rose to $\$ 704$ million in the fourth quarter of 2001 , exceeding the $\$ 630.2$ million of rival Travelocity and making it the top online travel agent. The company also reported its first quarterly profit, $\$ 5.22$ million.
For the past four years I have offered a hands-on community Internet workshop on travel. This guide has benefitted from the input and experiences of many who have attended these workshops.

\section{Where to go}

- Concierge. If you're trying to decide where to go, this is an excellent place to begin. Sponsored by Conde Nast Traveler, a popular travel magazine, the site lets you search by place, view poll results from the magazine on the best destinations and hotels or find a romantic getaway. For the winter season, the site featured the "Top 50 Ski Resorts in North America." The well-heeled can search the 2002 Gold List for the most elite hotels, resorts, and cruise lines in the world. The rest of us can check out the 2001 Readers' Choice Awards for cities, islands, hotels, resorts, small hotels, cruise lines, and services. Access: http://www.concierge.com.

- The Travel Channel. In addition to serving as an online guide to the cable channel of the same name, this is a perfect site for an undecided traveler. Click on "explore by destination" to plan a trip. Click on "explore by idea" for guides to beaches and islands, casinos and resorts, culture and attractions, and theme parks. You can even watch live cams in Las Vegas, Times Square, and South Beach. Access: http://travel.discovery.com/.

\section{About the author}

Brian Coutts is head of the department of library public services at Western Kentucky University, e-mail: brian.coutts@wku.edu 


\section{Travel guides}

- Fodors. Launched in 1996 by the world's largest English-language travel publisher, you can use this interactive site to create your own mini-guide to 200 destinations worldwide, complete with recommendations on hotels and restaurants, not to mention important sites to visit. Under "trip ideas" be sure to check out Fodor's "10 Underrated Getaways." Access: http://www fodors.com.

- Frommers. Click a region under "destinations" or type in the name of a country, region, state, or city to find information for your next holiday. Then you can check out hotels, restaurants, shopping, and nightlife for many popular locations. An added bonus at this site is a daily newsletter and hot tips from Arthur Frommer himself. Check the "Blockbuster Bargains" for info about discounted packages, airfares, cruises, lodgings, and car rentals. Access: http://www.frommers.com.

- Lonely Planet. This Australian travel guide publisher was founded in the early 1970 s by Tony and Maureen Wheeler after an overland journey from London through Asia to Australia. Their first guide, Across Asia on the Cheap, became a bestseller. This site provides virtual travel guides, complete with

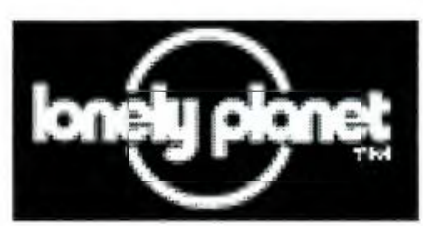
gorgeous pictures, for many tourist destinations. Click "worldguide" and find an interactive world "destinations" map. You can search by country or region to find info about attractions, off the beaten track, history, environment, and getting around. You can even sign up for one of their several newsletters. They donate a portion of their profits to organizations benefitting the people they cover. Access: http:// www.lonelyplanet.com.

\section{Travel bookstores/maps}

- Adventurous Traveler Bookstore. Stocking more than 10,000 books, magazines, and gadgets, this online store boasts one of the largest collections for outdoor adventure anywhere. Use the drop-down menu on the left to search for books or maps that are shipped from Burlington, Vermont. You can also check out their bargain basement sales. Access: http://www.adventuroustraveler. com.
- Maps.com. Founded in 1991, this site offers a combination of content and commerce and attracts a reported 1.7 million users per month. This is a one-stop site for maps of all sorts from wall to digital. You can also use the site for driving directions or to find an address. Access: http://www.maps.com.

\section{Travel information}

- Tourism Offices Worldwide Directory. True to its title, this site lists 1,445 official government tourist offices, convention and visitors bureaus, chambers of commerce, and similar agencies worldwide. Use the dropdown boxes at the top to search by country or state. Access: http://www.towd.com.

\section{Air travel}

- AOW: Airlines of the Web. Developed by Marc-David Seidel, a University of Texas business professor specializing in Internet marketing, this site allows consumers to shop on more than 500 airlines worldwide. Click on "cyberfares" to get the latest "hot deals," or check out "air tips" to get the most out of your travel. Access: http://flyaow.com.

- Microsoft Expedia. One of the oldest, most valuable travel sites on the Web. New features include online maps and vacation packages. Try their "express search" fare finder for a quick estimate on your next trip. You can also check their "traveler tools" for special information. Access: http://expedia.com.

- Orbitz. This is the newest of the "big three" travel Web sites founded less than a year ago by five airlines: American, Continental, Delta, Northwest, and United. You can use the Orbot Quick Flight to book a trip, check out flight deals, and locate a weekend Webfare. They even give warnings about possible travel delays. Access: http:// wrww.orbitz.com.

- Travelocity. Now six years old, having merged with Preview Travel, Travelocity provides access to 47,000 hotels, 50 car rental agencies, and 6,500 tour and cruise packages. A unique feature is their "fare watcher program," which allows you to monitor changes in prices for selected destinations. Access: http://www.travelocity.com.

\section{Train travel}

- Amtrak. Listing more than 500 destinations available on Amtrak, this site allows 
you to make reservations and purchase tickets online. Check "advertised specials," "savings and promotions," or "rail sale" for bargain travel opportunities. This is a great place to browse if seeing the United States by rail is your goal. A free password is needed to complete reservations. Access: http://www. amtrak.com.

- Rail Europe. Provides information on the 17-country Eurailpass, 5-country Europass, and Brit Rail passes, as well as single-country passes for France, Switzerland, and Italy. From here you can book all types of European rail passes and tickets online. For point to point tickets, check out "fares and schedules." Access: http://www.raileurope.com/us.

- Rocky Mountaineer. Billing itself as "The Most Spectacular Train Trip in the World," this private railroad offers spectacular trips from Vancouver through the Rockies to Alberta and back. The number of departures has grown from 40 to 148 in just 12 years. Access: http://www.rockymountaineer.com.

- VIA Rail Canada. With a motto of "Discover Canada with VIA," this is the Web site for Canada's national rail service, which operates 460 trains weekly serving 450 Canadian localities. Under "ways to save" check out the very affordable "CANRAILPASS." Access: http://WwW viarail.ca/en_index.html.

\section{Buses}

- Greyhound Lines Inc. This easy-to-navigate site makes it a breeze to book your next bus trip. If you already know your destination, click on "purchase tickets" for fares and schedules. Check out the " 2 for 1 Companion Fares" or the "Discovery Pass" for continental travel. Access: http://www.greyhound.com.

\section{Travel by car}

- MAPBLAST. After a free registration, this popular site provides users with interactive maps and driving instructions, as well as information on services and products near a user's address or travel route. Be sure to try out their brand new "Line Drive Directions," which get you to your destination turn by turn. Access: http://www mapblast.com.

- MapQuest. Originally founded by R. R. Donnelly \& Sons in 1966 as a cartographic services division, this is one of the busiest sites on the Web. From here you can plot driving directions, locate addresses, and develop personalized maps. Access: http:// www.mapquest.com.

- Moto Europa. Provides a one-stop guide to car travel in Europe with information on highways, fuel costs, and road signs. Under logistics check "documents and $\$$ " for driving particulars for each country. They also promote short-term leases with Renault. $A c$ cess: http://www.ideamerge.com/motoeuropa.

- Rental Cars. Breeze.Net's guide to more than 90 major airport auto rental companies and franchises at more than 170 airports. Look for the 11th Hour Specials if you're hunting for a bargain. Access: http:// www.bnm.com.

- Roadside America. From the world's largest sycamore tree to a tour of the Crayola factory, you can find it here. Use the "electric map" to find the strange and unusual attractions along the road for your next trip. $A C$ cess: http://Www roadsideamerica.com.

\section{Hotels and motels}

- all-hotels. While the title of this site overstates its comprehensiveness, it does provide links to more than 60,000 hotels in 9,600 locations. Beautifully designed, this is one of the oldest online guides to hotels. Type in your location at the top and click "go." Accommodations are organized by price range from discount to luxury. Access: http:// www.all-hotels.com/home.htm.

- AsiaTravel. Featured on the Singapore Stock Exchange, this is one of Asia's largest Internet-based hotel reservations and travel service providers. More than 5,000 hotels and resorts can be previewed and booked from this site. Discounts of up to 75 percent are offered for online reservations. They are now booking hotels in the Middle East and many other parts of the world. Access: http:// asiatravel.com

- HotelsTravel.com. Provides more than 75,000 links to lodgings and travel resources worldwide. Click on "hotels" at the top. From here you can click on "hotel chains" for one of the most complete lists anywhere. Access: http://www.hotelstravel.com.

- Lodging.com. This site was founded in 1995 by two high school friends who were avid skiers in Boca Raton, Florida. Since then the company has expanded to offer online info for 5,000 U.S. cities. With more than 10,000 
bookings per month, the company continues to expand. Access: http://www.lodging.com.

- Placestostay.com. A division of WorldRes.com founded in 1995, this Internet company lists more than 28,000 bed and breakfasts, ski resorts, inns, and hotels, including many independents. Access: http://www. placestostay.com.

- Roomsaver. If you've ever picked up those green traveler discount guide hotel coupons at state welcome stations, then you're familiar with Roomsaver. Now you can print your very own online coupon book for your next trip, selecting from some 6,000 discounted hotel rooms. Access: http://www. roomsaver.com/roomsaver.

\section{Bed and breakfasts}

- Educators Bed and Breakfast Travel Network. This membership site covers 52 countries where 5,000 educators share their homes with

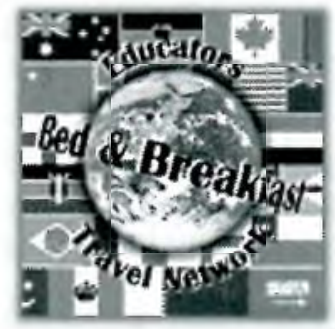
other educators interested in less expensive room and board. Members agree to provide double accommodations for $\$ 32$ or a $\$ 30$ single. A current online directory lists homes available. Their newest feature is "home stays," where members may housesit for $\$ 40$ a night. There is a $\$ 36$ annual membership and a $\$ 10$ one-time registration fee. Access: http://www.edubabnet.com

- Internet Guide to Bed and Breakfast Inns. Tired of staying in hoteis? This site offers unique, comfortable, and often less expensive lodgings and dining opportunities. Online since 1995, this site links you to more than 6,000 bed and breakfast inns in North America and around the world. Phone numbers, addresses, rate and availability are kept relatively current. Access: http://www. traveldata.com/inns.

\section{Home exchanges}

- International Home Exchange Network. Now in its seventh year, worldwide hospitality listings offered at this site provide current opportunities to exchange residences at little or no cost to either participant. You can list your residence online and search for listings in areas you would like to visit. $A C$ cess: http://www.homeexchange.com.

\section{Cultural events}

- CultureFinder. Planning a trip to New York? Want to check the availability of tickets for the latest Broadway show? CultureFinder is the place to do it. You can check out national tours, classical/opera, dance, theater, and visual arts in 1,500 different cities. Access: http:// www.culturefinder.com.

\section{Adventure travel/outdoor recreation}

- Away.com. With more than 5,000 trips offered by 200 adventure travel companies, this is a terrific site for the adventurous traveler! Click on "trip finder" by region or activity to find out about super trips. You can sign up for one of their "daily escapes" to a foreign destination or subscribe to one of their colorful newsletters about exotic locales. They even provide color calendar screensavers. Access: http://away.com

- GORP Great Outdoors Recreation Page. Founded by Diane and Bill Geer in 1995, with more than 100,000 pages, GORP is the largest Web site devoted to outdoor recreation and adventure travel. Click on your favorite activity to locate interesting trips from biking to wildlife viewing. Access: http://www.gorp.com.

\section{Cruise travel}

- Cruise.com. Owned by Omega World Travel founded in 1972, this is one of the largest travel agencies in the United State. Their Web site, established in 1998, tells you just about every thing you want to know about cruising from "ship reviews" to "ship stats." Cruise.com now claims to be the Internet's largest cruise seller. Access: http://www.cruise.com.

\section{Special deals}

\section{A. Airlines}

Most domestic and many international airlines provide special weekend cyberfares. For most of these you must leave on a Friday or a Saturday and return on a Monday or a Tuesday. These special offers can be e-mailed to you weekly. They usually arrive on Tuesday or Wednesday.

- Air Canada Websavers. Click on the "websaver" box under "quick links" for weekend specials. Access: http://www aircanada. $\mathrm{ca} /$ home.html.

- American Net SAAvers. Click on Net SAAvers and special offers. Access: http:// www.aa.com. 
- Best Fares Online. This is the online version of Tom Parson's Best Fares Magazine. While the inside scoop goes to paid members, you can try out the "city low fare finder." Access: http://www.bestfares.com.

- Cathay Pacific. Click on "CyberTravelerProgram" for e-mail offers, auctions, and the "All Asia Pass." Access: http://www.cathay.ca.

- Continental Airlines. Click on "vacations and specials" for their weekend specials. Access: http://www.continental.com.

- Delta Web Fares. From links on the left, click on "special offers." Access: http:// www.delta.com

- Northwest Airlines. Click on "deal and promotions" for their weekly "CyberSavers." Access: http://www.nwa.com.

- Southwest Internet Specials. Unlike the other weekend specials, Southwest's are good anytime and offer huge discounts, which must be booked quickly since they go fast! Click on "systemwide fare specials!" for their click "click 'n save specials." Access: http:// www.iflyswa.com.

- United Airlines. Click on "special deals" for domestic and international sales. Access: http://www.ual.com.

- US Airways. Click on "promotions" for this week's "E-Savers." Access: http://www. usairways.com.

\section{B. Auctions}

- Priceline.Com. A new innovation in air travel. You name the price you're willing to pay for tickets and priceline finds a major airline willing to release seats on flights where they have unsold space. Caution! Once your bid is accepted you are committed. You can also bid for hotel rooms and rental cars. $A C$ cess: http://www.priceline.com.

- Sky Auction.com. This exciting company lets you bid on airline tickets, hotel stays, packages, and resort vacations worldwide. Click on "auctions closing soon" to watch closing bids. You can even check out deals by location. Be sure to add in their tax and service charge of \$195. Access: hitp://www.skyauction.com.

\section{Miscellany}

\section{A. Travel Aids}

- RCM Travel Site. Launched by a small marketing company in Mississippi in 1997, the RCM Travel Site provides links to currency converters, map services, distance finders, and weights and measures. Access: http://rcmtravel site.com/Travel _Aids.

\section{B. Languages}

- TravLANG. Provides information on 70 different foreign languages, including guides to basic words, help on pronunciation, etc. Access: http://www3.travlang.com.

\section{Festivals}

- Festival Finder. Here you can find information on more than 2,500 festivals in North America. Click on your favorite genre or locate festivals by date, location, performers, or festival name. Access: http://www. festivalfinder.com.

\section{Newsletters}

- This Week's Top 20. This online newsletter lists the top 20 travel bargains of the week. Access: http://top20.travelzoo.com.

- Welcome to Igougo. A terrific site that allows you to read travel journals written by other tourists or write one yourself. Be sure to check out their 30,000 photos. Access. http://www.igougo.com.

\section{E. Senior Travel}

- INTERHOSTEL. Now celebrating its 22nd anniversary, Interhostel sponsors learning vacations for adults over the age of 50 . A newer program, FamilyHostel is designed for families with school-aged children. Access: http://www.learn.unh.edu/INTERHOSTEL.

\section{F. Student Travel}

- AESU Online. Since 1977, AESU has offered special European travel packages for college students 18 to 35. Access: http:// www.aesu.com.

\section{G. Time Zones}

- time and date.com. This is a great place to check world time zones and calendars. $A C$ cess: http://www.timeanddate.com.

\section{H. Travel Warnings}

- Travel Warnings \& Consular Information Sheets. Travel warnings are issued by the U.S. State Department to inform Americans that they should avoid travel to a certain country. Consular Information Sheets locate U.S. embassies or consulates and describe conditions in each country. Access: http:// travel.state.gov/travel_warnings.html. http:/www.ala.orglacr/resapr02.html 